\title{
Pojęcie serca jako źródła cnót w refleksji Filona z Aleksandrii
}

\author{
ks. Krzysztof Kuderski \\ Chrześcijańska Akademia Teologiczna w Warszawie \\ Polska \\ studentusk@wp.pl
}

rev. K. Kuderski, The concept of the heart as the source of virtues in the reflection of Philo of Alexandria, Elpis, 20 2018: 65-69.

\begin{abstract}
Heart is one of main notions used in the works of Philo of Alexandria. They are interpreted in an allegorical way. Philo points the close connection of mind and heart. In his opinion, the heart performs the role of managerial and giving mind. Through heart can grow in Christian virtues. Thanks to virtues the man can approach God.
\end{abstract}

\begin{abstract}
Streszczenie: Serce jest jednym z głównych pojęć pojawiających się w dziełach Filona z Aleksandrii. Jest one interpretowane w sposób alegoryczny. Filon wskazuje na ścisły związek serca z umysłem. W jego odczuciu, serce spełnia rolę kierowniczą i ożywiającą
\end{abstract} umysł. Po przez serce człowiek może doskonalić się w cnotach chrześcijańskich. Dzięki cnotom człowiek zbliża się do Boga.

Keywords: God, virtue, human, being, soul, mind, heart

Słowa kluczowe: Bóg, cnota, człowiek, dusza, umysł, serce

\section{Wstęp}

Filona z Aleksandrii jest jednym z największych żydowskich mędrców pierwszego wieku po narodzeniu Chrystusa, którego twórczość wpłynęła na chrześcijańską refleksję teologiczną. Filon z Aleksandrii przyczynił się do powstania szkoły aleksandryjskiej i był przedstawicielem alegorycznej interpretacji Pisma Świętego. W jego dziełach pojawia się alegoryczna interpretacja pojęcia serce. $\mathrm{Na}$ jego nauce bazowali wielcy myśliciele i przedstawiciele szkoły aleksandryjskiej. Słowo „serce” rzadko występuje w tekstach filozofa z Aleksandrii. Kiedy jednak używa tego pojęcia zawsze odwoluje się on do jego znaczenia symbolicznego. Najczęściej serce umieszcza on wśród symboli biblijnych o znaczeniu etycznym, które posiadają ukryte znaczenie i potrzebują, aby człowiek za ich pośrednictwem mógł „zobaczyć niejawne przez jawne". Symbole ust, serca i rąk wskazują na wewnętrzną istotę człowieka, która realizuje się przez słowa, przykłady, zamysły i działania. Połączenie tych symboli podkreśla harmonię myśli, słów oraz uczynków. Taka właśnie zgodność cechuje, według Filona z Aleksandrii, cnotliwego człowieka²

\section{Pojmowanie symbolu serca przez Filona Aleksandryjskiego}

W tekstach Filona Aleksandryjskiego występują dwa charakterystyczne fragmenty ujawniające jego rozumienie

\footnotetext{
Por. Е. Д. Матусова, Филон Александрийский, Москва 2000, s. 35.

2 Por. M. Osmański, Filon z Aleksandrii. Etyka upodabniania się do Boga, Lublin 2007, s. 225.
}

symbolu serca. Za pośrednictwem symbolu, którym jest serce, Filon wskazuje na ścisły związek serca pojmowanego cieleśnie z sercem w rozumieniu duchowym. W jego rozumieniu metafizyczne głębie ludzkiej istoty jakby wrastają w organ cielesny: „Jak może być prawdopodobne, żeby coś tak małego jak ludzki umysł, zawierający się w małych przestrzeniach mózgu lub serca, mógł pomieścić tak wielkie niebo i wszechświat i być nieoddzielnym od boskiej i szczęśliwej duszy. Prawda, że to, co boskie, nie jest odrywane, a tylko rozciągane. Dlatego kiedy przedmiotem umysłu są myśli związane z kosmosem, rozszerza się razem z nim do granic, nie podlegając rozerwaniu: jemu właściwa jest rozciągliwość”’

W tym kontekście serce, jako organ cielesny, obejmuje metafizyczny umysł, rozumną część ludzkiej duszy, który jest nieoddzielną częścią Boskiego Logosu. Serce występuje tutaj jako pośrednik wiążący człowieka ziemskiego i niebiańskiego, jednający życie śmiertelne z nieśmiertel$n^{4}{ }^{4}$. Nieśmiertelna natura duszy zawiera w sobie umysł - pochodzący od Boga dar, który jest jego obrazem i ma funkcję noetyczną̧. Połączenie w duszy człowieka tych dwóch, na pierwszy rzut oka przeciwstawnych rzeczywistości, zostało przez Filona opisane za pomocą alegorii. Filon pisze, że zalążek ,złego drzewa” odcina się przy samym korzeniu, zaś w nim, uprzednio oczyszczonym, robi się płytkie nacięcie, w którym umieszcza się zalążek „dobrego drzewa”. Obie części duszy tworzą wtedy jedną naturę, w ramach której między sobą dokonują swoistej

\footnotetext{
Филон Александрийский, О том, что худшее склонно нападать на лучшее, 90, [w:] Е. Д. Матусова, Филон Александрийский, dz. cyt., s. 218.

4 Tamże, s. 219.

5 Tamże, s. 217.
} 
wymiany mocy: , Korzenie wspomagają zalążek i nie pozwalają mu zwiędnąć, a on daruje im owoce"

W drugim fragmencie filozof także wskazuje na wartość oraz związek mózgu i serca z rzeczywistością duchową. W traktacie $O$ ofiarach Abla $i$ Kaina pisze: „Prawa o składaniu ofiary zezwalały na ofiarowywanie jako pierwszych tłuszczu ofiary, jej nerek i wątroby. (...) Nigdzie jednak nie jest napisane o mózgu lub o sercu, a wydaje się, że akurat te organy w pierwszej kolejności należało złożyć w ofierze, gdyż sam Dawca Prawa stwierdza, że w tych dwóch organach zawiera się istotne źródło. Te ofiary nie zostały jednak dopuszczone do ołtarza Bożego. Mogłoby się wydawać, że głęboka pobożność i rozmyślanie prowadzące do źródła obraca się w potoku czasu, zwracając się to do lepszego, to do gorszego, i przyjmuje odznaki różnych monet, to oryginalne i miarowe, to starte i fałszywe" "Wyjaśniając przytoczony fragment można postawić tezę, że identyfikacja mózgu i serca jako „istotnego źródła" wskazuje, że tam dokonuje się proces decyzyjny człowieka, polegający na zwracaniu się ,to do lepszego, to do gorszego". Zatem w swoim umyśle i sercu człowiek wybiera drogę prowadzącą ku oczyszczeniu i dobru. W pismach Filona można także znaleźć wiele wzmianek odnoszących się do serca lub głowy jako miejsc w ciele człowieka, które są związane z aktem stwórczym. Po pierwsze, określając człowieka ,jedyną niebiańską rośliną na ziemi”, wyjaśnia on, że w odróżnieniu od zwierząt, człowiek ma głowę, którą kieruje ku górze, aby „za pośrednictwem wzroku, będącego najdoskonalszym ze zmysłów, zbliżał się do słońca i do każdej innej konstelacji, do planet i gwiazd stałych"s. W ten sposób ma naturalną przyrodzoną zdolność poznawania i kontemplowania Boskiego dzieła stworzenia i jego Stwórcy: „Bóg, tworząc człowieka, zakorzenił stopnie jego ciała w ziemi, (...) zostawiając wszystko w nieczułym ciele, oprócz części stojącej najwyżej, czyli inteligencji. (...) Oddzielił On umysł i uczucia od części ziemskiej, łącząc je tym samym z niecielesnym krę-

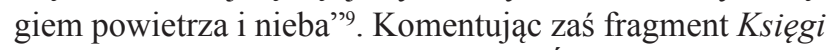
Rodzaju (Rdz 2, 6) Filon stwierdza: „Źródło wznosiło się nad ziemią i zraszało wszystkie twarze na ziemi”. Mówiąc o źródle Filon ma na myśli umysł, którego idee, niczym deszcz, zraszają ,inne twarze”, czyli są inspiracją dla innych poszukujących mądrości umysłów.

Do symboliki serca Filon nawiązuje w traktacie $O$ potomstwie Kaina, dostrzegając w pustym dzbanie Rebeki ${ }^{10}$ oraz w traktacie $O$ stworzeniu świata, w którym praobraz serca dostrzega w symbolu rajskiego drzewa życia, które było zasadzone w środku rajskiego ogrodu, symbolizującego umysł. Warto jednak przyjrzeć się tej interpretacji,

\footnotetext{
6 Por. tenże, 107-108, [w:] tamże, s. 222.

Филон Александрийский, О жертвоприношениях Каина и Авеля, 136-137, [w:] Е. Д. Матусова, Филон Александрийский, dz. суt., s. 188. Filon Aleksandryjski, O stworzeniu świata, 147, [w:] tenże, Pisma t. 1, tł. L. Joachimowicz, Warszawa 1986, s. 73.

9 Филон Александрийский, О том, что худшее склонно нападать на лучшее, 85, [w:] Е. Д. Матусова, Филон Александрийский, dz. суt., s. 217.

10 Tenże, O потомстве Каина, 137, [w:] Е. Д. Матусова, Филон Александрийский, dz. cyt., s. 281.
}

chociaż - jak zauważa E. Matusowa - u Filona nie jest ona zbyt konsekwentna i jej odczytanie napotyka na bardzo wiele trudności ${ }^{11}$.

Filon interpretuje rajski ogród jako alegorię umysłu miejsce zamieszkania wszelkich cnót. W traktacie $O$ stworzeniu świata pisze on: „Mojżesz (...) symbolicznie wskazuje przez ten ogród na kierującą część duszy, napełnioną przez niezliczone wyobrażenia na podobieństwo roślin. Przez drzewo życia czyni aluzje do cnoty najpiękniejszej ze wszystkich, jaką jest bojaźń Boża, która zapewnia duszy wieczne życie, a przez drzewo poznania dobra i zła daje do zrozumienia, że chodzi o roztropność, jako cnotę pośrednią, pozwalającą odróżnić rzeczy z natury sobie przeciwne"12. Chociaż nie jest to wyraźnie powiedziane to jednak nawiązując do starotestamentowej idei serca można przypuszczać, że pod pojęciem drzewa życia Filon rozumie właśnie serce. Ono jest bowiem źródłem życia i w nim mieszka bojaźń Boża, która jest początkiem mądrości. Serce jest centralnym organem ożywiającym zarówno umysł, jak i ciało. Inspiracje (energie) płynące stamtąd skłaniają człowieka do poznania prawdy i praktykowania cnót, które Filon postrzega jako pozostałe drzewa rajskiego ogrodu. Rozważania na temat rajskiego ogrodu są dla Filona okazją do przedstawienia jego nauki o cnotach, w której można zauważyć wiele wątków stoickich. Według Filona istnieje hierarchia cnót. W pierwszym rzędzie są one atrybutami Boga, ale także człowieka, który został stworzony na Jego obraz i podobieństw. Człowiek, dzięki praktykowaniu cnót realizuje swoje powołanie i pozostaje w przyjaźni z Bogiem. W ten sposób istnieje w zgodzie ze swoją naturą ${ }^{13}$. Najważniejszą z nich jest cnota czci Boga, którą symbolizuje ,jedyny potok" - rzeka, która wypływa z Edenu. Filon określa ją jako „wieczne dziewictwo”, którego „nie poznał żaden człowiek”. Jej nieskazitelna natura jest niedostępna poznaniu i żadnemu śmiertelnikowi nie pozwolono ,jasno zrozumieć, jaka ona jest" ${ }^{14}$. To, w jaki sposób pisze o tej cnocie Filon przywodzi na myśl ludzkie serce, o którym w Starym Testamencie powiedziano, że jest ono niezbadane, przenika je i zna dogłębnie wyłącznie Bóg. Także słowa Chrystusa, który mówił, że należy kochać Boga całym sercem wskazują, że prawdziwa cześć odbiera Bóg w sercu człowieka. Z serca zatem, które symbolizuje wiarę w Boga polegającą na Jego miłowaniu, jak ze źródła, wypływają potoki innych cnót, które Filon identyfikuje jako rozumność, odwaga, wstrzemięźliwość, sprawiedliwość. Te cnoty są wyrazem miłości do Boga. Są więc boskimi mocami, które pozwalają właściwie orientować się w otaczającym świecie i prowadzić człowieka do Boga. Można powiedzieć, że ich właściwe praktykowanie są znakiem kierowniczej roli serca, która wyraża się w dążeniu umysłu do doskonałości.

Chociaż serce w filozofii Filona spełnia rolę kierowniczą i ożywiającą umysł, człowiek po upadku utracił wła-

\footnotetext{
Е. Д. Матусова, Филон Александрийский, dz. cyt., s. 31-32.

12 Filon Aleksandryjski, O stworzeniu świata, 154, [w:] tenże, Pisma, t. 1, dz. cyt., s. 76.

13 Por. M. Osmański, Filon z Aleksandrii..., dz. cyt., s. 202.

14 Tamże, s. 280.
} 
ściwe zrozumienie natury rzeczy i samego siebie. Dlatego cnoty, które człowiek posiada z natury, potrzebują pielęgnacji, aby mogły być - jak stwierdza Filon - drzewami „rodzącymi dobro i przynoszącymi plon”15. Do tego potrzebna jest woda z mistycznego źródła, którym jest serce. Warto przywołać tutaj podany przez Filona przykład niewolnicy Hagar dającej pić swojemu dziecku w bukłaka z wodą (zob. Rdz 24, 16-20). W swoich rozważaniach Filon zestawia postać Hagar z postacią Rebeki. Pisze on, że Hagar symbolizuje nauki materialne i ziemskie oraz poi swoje dziecko z bukłaka symbolizującego ziemskie i materialne nauki. W odróżnieniu od niej Rebeka, która uosabia wzniosłe i niebiańskie nauki, aby napoić sługę, napełniła swoje naczynie w źródle. Filon wskazuje tutaj na dwie drogi kształtowania się cnót - ziemską i niebiańską. Owo źródło, z którego czerpie Rebeka, może być identyfikowane z sercem. Dlatego symbolizuje ona dobrą i niezniszczalną cnotę, której treścią jest miłość, która nie pozawala pominąć w potrzebie nawet sługi. Hagar zaś poi wyłącznie własne dziecko, dziecko według ciała. Cnota, którą symbolizuje, nie jest doskonała, gdyż ogranicza się do świadczenia dobra jedynie swoim najbliższym, a nie każdemu człowiekowi. Ma ona zakorzenienie nie w sercu, ale w rozumie, którego symbolem jest bukłak.

Skoro serce jest centrum umysłu i fundamentem cnót, należałoby rozważyć, czym dla Filona jest umysł - medium, przez które serce ujawnia swe zamysły, i jakie są jego właściwości.

Według Filona z Aleksandrii obrazem, z którego został stworzony umysł człowieka, był nie sam Bóg, ale obraz Boga - Logos. Filon w traktacie $O$ stworzeniu świata stwierdza, że człowiek stał się „odwzorowaniem i naśladownictwem" Logosu, który stał się wzorcem dla jego duszy $^{16}$. Logos u Filona jednocześnie ukazuje obraz Boga i odbicie, archetyp odczuć. Logos to zasada stwarzania, ale nie Stwórca ${ }^{17}$.Ukazywany jest jako „narzędzie” wykorzystane przez Boga podczas aktu stworzenia ${ }^{18}$. Filon pisząc o ludzkim umyśle, który jest obrazem Logosu, dodaje również, że Logos jest także modelem powstania świata. Świadczy to o tym, że nastąpiło zrównanie człowieka ze światem, a przez to wyróżnienie go ze wszystkich stworzonych bytów, ponieważ dysponuje umysłem. Z tego kontekstu można wywnioskować, że umysł człowieka zawiera w sobie odbicie boskiego Logosu. O ludzkim umyśle Filon wspomina jako o trzecim odbiciu Boga ${ }^{19}$. W pismach Filona można wielokrotnie zauważyć niższość Logosu w stosunku do $\mathrm{Boga}^{20}$. Filon podkreśla także to, że człowiek został stworzony na obraz „drugiego boga”, gdyż „Bóg jest wcześniejszy od Logosu"21.Należałoby na problem podobieństwa człowieka do Logosu spojrzeć z perspektywy bo-

\footnotetext{
15 Tamże, s. 223.

16 Por. tamże, s. 80.

Tamże, s. 85.

Por. tamże.

Por. Filon Aleksandryjski, O stworzeniu świata, 83, [w:] tenże, Pisma,

t. 1 , dz. cyt., s. 56

20 Por. M. Osmański, Filon z Aleksandrii, dz. cyt., s. 85.

21 Por. tamże, s. 90
}

skiej relacji Logosu do Stwórcy. Człowiek, który jest podobny do Logosu, ,jest jednocześnie podobny do Boga"22. Interesujące jest to, że charakter podobieństwa rozumu człowieka do boskiego Logosu posiada kilka archetypów: jako odbicie, cząstka, odblask, błogosławiona natura i nawet cielesny układ na podobieństwo logosu całego świata.

\section{Trójwymiarowość duszy}

Wielokrotnie rozumną duszę Filon nazywa trójwymiarową. Jej wymiarami są: umysł, słowo i czucie. „W nas samych - pisze on - są trzy wymiary: czucie, mowa, umysł. Miarą oczyszczającą jest czucie, miarą imion, słów i wszystkiego wymawianego - mowa, a miarą wszystkiego o czym się myśli - umysł"23. Pojęcie ,wymiaru” u Filona wybitnie odnosi się do stworzenia. Sam boski akt stworzenia przedstawia on jako „odmierzanie”, a więc stawianie granic temu, co zostało stworzone. Boża łaska, która jest bezgraniczna, przekazuje stworzeniu właściwe dary, które pozwalają mu funkcjonować „na swoją miarę”, a więc w określonej przez Boga hierarchii stworzeń. Filon stwierdza: „W stworzeniach Boga odnajdziesz bez skazy sens oraz nienaganne miary prawdy" 24 . W ten sposób trzy miary ludzkiej duszy można rozumieć jako boskie idee, które są obecne w ,ziemskim człowieku”. W tym kontekście warto przypomnieć sobie o sercu, o którym powyżej wspomniano jako rzeczywistości nie „mającej miary”, miejscu zamieszkania Bożego obrazu w człowieku. Triada czucie, mowa i umysł organizuje wyjątkową sferę aktywności człowieka, którą jest wypowiedź jako formułowanie myśli - myśli pochodzących z niezbadanej głębi, którą jest waśnie serce. Nieprzypadkowo sam Jezus Chrystus głosił, że w sercu rodzą się wszystkie myśli, które potem przybierają postać słów. Każde wypowiadane słowo są przez Filona jest określane mianem „brata rozsądku”. Umysł, który jest wprawiany w ruch przez serce artykułuje myśli. Myśli choć pomyślane, a następnie wypowiadane są jednak skryte - jak stwierdza Filon - „w ciemności”, a więc w sercu, które jest niezbadane i które zna jedynie Bóg ${ }^{25}$.

Pierwotnie trzy wymiary duszy były ze sobą w harmonii. Filon pisze: „Na podobieństwo instrumentów muzycznych, dźwięczących nienagannie, my brzmieliśmy w zgodzie ze wszystkimi pouczeniami"26. Współbrzmienie sił duszy oznaczało podporządkowanie się wszystkich sił jednemu początkowi, ,jedynemu ojcu" - sercu ${ }^{27}$.

Rozdźwięk między nimi był konsekwencją grzechu pierwszych ludzi, który „odciął” je od źródła, którym jest

\footnotetext{
22 Por. tamże, s. 91.

23 Филон Александрийский, О соитии ради обучения 100, [w:] Е. Д. Матусова, Филон Александрийский, dz. cyt., s. 370.

24 Tenże, О том, что худшее склонно нападать на лучшее 125, [w:] Е. Д. Матусова, Филон Александрийский, dz. суt., s. 225.

25 Tamże, 126, [w:] Е. Д. Матусова, Филон Александрийский, dz. суt., s. 226.

26 Tamże, 55, [w:] Е. Д. Матусова, Филон Александрийский, dz. суt., s. 316 .

27 Tamże, 43, [w:] Е. Д. Матусова, Филон Александрийский, dz. суt., s. 314 .
} 
serce. Od tego czasu myśli realizują się głównie w cielesności, którą Filon określa mianem „największego zła”. Nieprzypadkowo wąż, który skusił Adama i Ewę, wystąpił przeciw cielesności uznając ją za najsłabszy punkt ludzkiej natury. Przedstawiając alegorię grzesznego upadku Filon wspomina o tym, że zaistniał tutaj wybór między podążaniem wiedzy, które pierwsi ludzie chcieli zaspokoić skosztowaniem widzialnego, smacznego owocu poznania dobra i zła a otrzymaniem szczęśliwego udziału w życiu wiecznym poprzez realizację duchowej cnoty mądrości wynikającej z posłuszeństwa Bożemu nakazowi. Dążenie do doskonałości duchowej chcieli zrealizować drogą „na skróty” poprzez cielesność, co - jak stwierdza Filon - „w jednym momencie zmieniło ich oboje”. Adam-umysł zachorował na „nieuleczalną chorobę" - brak rozsądku i został wygnany $z$,miejsca wszelkich cnót”28. Grzech wykopał przepaść między sercem i umysłem, oddzielił umysł od serca, wskutek czego umysł utracił kontakt ze źródłem, z którego czerpał. Wyrazem tego jest wygnanie $\mathrm{z}$ raju, zagrodzenie ludziom drogi do drzewa życia przez anioła z ognistym mieczem. Zbrukanie obrazu Bożego w człowieku oznacza więc zbrukanie serca, wskutek czego nastąpiło wprowadzenie do ludzkiego umysłu niedoskonałości, która spowodowała „zaciemnienie” lub „osłabienie” zdolności poznawczej, a także zdolności moralnej. Rozum zaczyna chłonąc przeciwstawne wartości - pojmowanie i niepojmowanie, cnotliwość i rozwiązłość, dobro i zło, piękno i brzydotę, dobrodziejstwo i skazę. Umysł staje się zatem miejscem przebywania zarówno wad, jak i cnót. Filon, opisując tę zmianę w duszy, wskazuje na trzy jej aspekty związane $\mathrm{z}$ umysłem i rozumem, duchem oraz pragnieniem. Umysł i rozum ukazują racjonalny początek; duch - początek nierozumny, przez który człowiek się zakochuje, a pragnienie - początek emocjonalny ${ }^{29}$. Wskutek grzechu umysł „wbił się w pychę" i autorytarnie zadecydował, że wszystko, co go otacza, należy do niego. Stracił umiejętność panowania nad tym co zmysłowe i dał się uwieść namiętnościom ${ }^{30}$.

Filon odnosi próżne i zmysłowe poznawanie do obrazu miasta. Budynek w mieście symbolizuje wymysły ludzkie, mieszkańcy - pozornych mędrców nieznających prawdziwej mądrości, prawo - powszechnie dozwolone przewinienia, głupotę, samowolę. Ułomny obraz myśli prowadzi do zniszczenia boskich „miar” w duszy: myślenia, czucia i słowa. Niegodne słowa człowieka dążą do zniszczenia wszystkiego, co dobre, a odczuwalne spostrzeżenia pożerają i rozdzierają umysł. Jak stwierdza Filon: „Umysł jest słońcem naszej złożonej całości. Jeśli w człowieku, który jest maleńkim wszechświatem, on nie wzejdzie i nie ukarze swojej wyjątkowej światłości, okryje wszystkie funkcjonujące [rzeczy] głębokim mrokiem i niczemu nie

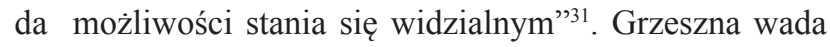

\footnotetext{
28 Филон Александрийский, О Херувимах ,10, [w:] Е. Д. Матусова, Филон Александрийский, dz. cyt., s. 115.

29 Tenże, O смешении языков, 21, [w:] Е. Д. Матусова, Филон Александрийский, dz. cyt., s. 342.

30 Por. M. Osmański, Filon z Aleksandrii..., dz. cyt., s. 170.

31 Филон Александрийский, О потомстве Каина, 58, [w:] Е. Д.
}

niszczy rozumną naturę duszy, kaleczy i odcina wszystko, co jest w niej piękne: rozumienie, wytrwałość, sprawiedliwość, pobożność i pozostałe cnoty. Przebywanie w odczuwalnym istnieniu zmniejsza siły umysłu. Oznacza to, że bezbożny człowiek nie osiągnie celu i odczuwa jeszcze większe męki przez to, że jego czyny nie zwiększają sił, lecz je zmniejszają" ${ }^{32}$.

Celem umysłu jest wejście na nowo w harmonię z sercem, dzięki czemu odzyska on swoje metafizyczne istnienie. To metafizyczne istnienie łączy się $\mathrm{z}$,upodobnianiem

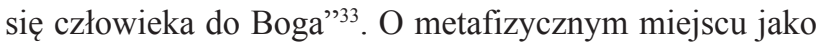
telosie umysłu jest mowa w objaśnieniu Filona do fragmentu Księgi Rodzaju (Rdz 22, 3-4): „Abraham, przybył na miejsce, które wskazał mu Bóg, na trzeci dzień wzniósł swoje oczy i zobaczył to miejsce $\mathrm{z}$ daleka". Filon pisał: „Mędrzec zawsze dąży do tego, aby ujrzeć Sprawcę Wszechświata; za każdym razem, kiedy kroczy on po drodze, przechodzi między wiedzą i mądrością. Spotyka się z boskimi słowami, przy których się zatrzymuje, żeby dojść na koniec drogi, gdzie zamierzal, ale nie podjął działań. Gdy oczy jego umysłu otworzyły się i jasno zobaczył, że jest trudną do osiągnięcia zdobyczą, ciągle wymykającą się swoim prześladowcom, zawsze oddaloną od nich na większą odległość i zostawiającą ich bez końca daleko z tyłu" 34 .

W powyższych słowach Filon opisuje drogę oczyszczenia polegającego do odnowienia relacji między sercem i umysłem. Aby scharakteryzować drogę prowadzącą do tego zjednoczenia Filon posługuje się alegorią nawiązującą do treści i znaczenia trzech wielkich świąt żydowskich: Paschy, Dnia Zjednoczenia oraz Dnia Oswobodzenia. Ta droga ukazuje gorliwą i długą pracę nad doskonaleniem duszy. Ta swoista katharsis duszy, droga ku sercu, to $\mathrm{w}$ istocie asceza.

Pierwszy stopień ascezy Filon wyjaśnia jako Duchową Paschę, która symbolizuje przejście od namiętności przez oczyszczenie do stanu myślenia i dążenia do Boga. W duszy, w której pojawia się namiętność, konieczne jest „rozdzielenie”: oddzielenie tego, co czyste (ofiary składane Bogu) od tego, co nieczyste (egocentryczne skupienie na sobie). Do tego co „czyste” odnosi się cnota, zaś do „nieczystego" - namiętność. Nierozumne moce bywają zaś dwojakiego rodzaju: niegodziwe działanie na przekór głosu serca i wypaczenie rozumu. Prymitywizm człowieka nieuczonego leczony jest nauką. Umysł hartuje się dzięki zajmowaniu się sztuką lub rzemiosłem. Rozwijanie zdolności pojmowania, wytrwałości, pamięci, uwagi, jest doskonaleniem myśli. Cnoty budowane na tym fundamencie są widzialne i zniszczalne na tyle, na ile są związane ze zniszczalnym człowiekiem ${ }^{35}$. Na danym stopniu ascezy

Матусова, Филон Александрийский, dz. суt., s. 263.

32 Tenże, О том, что худшее склонно нападать на лучшее, 114 ,

[w:] Е. Д. Матусова, Филон Александрийский, dz. суt., s. 223.

33 Por. M. Osmański, Filon z Aleksandrii..., dz. cyt., s. 173.

34 Филон Александрийский, О потомстве Канна, 18, [w:] Е. Д. Матусова, Филон Александрийский, dz. суt. s. 255.

35 Tenże, ОХерувимах, 5, [w:] Е. Д. Матусова, Филон Александрийский, dz. cyt., s. 115 . 
ważnym elementem w działaniu jest umysł. W rezultacie „czyste” moce duszy oddzielają się od ,nieczystych” i myśli się doskonalą. Oznacza to, że relacja z sercem została nawiązana.

Alegorią drugiego stopnia ascezy jest Dzień Zjednoczenia, w którym dusza nabiera przekonania o bezużyteczności samego rozsądku i uznaje wyższość serca, czyli wyższość i pierwszeństwo Niestworzonego. To zdarzenie przedstawia zmianę relacji duszy z Bogiem polegającą na zmaganiach w sercu i umyśle polegające na wzmocnieniu zbudowanej w poprzednim etapie więzi. Serce powoli przejmuje kontrolę nad umysłem, natomiast umysł coraz bardziej czerpie z boskich energii serca.

Trzeci stopień ascezy Filon wyjaśnia jako Dzień Oswobodzenia. Jest to wydarzenie pełnego uwolnienia duszy z niewoli błędnego zrozumienia. Serce ponownie staje się centrum władz duszy. Umysł doznaje oczyszczenia i jest zdolny do przyjęcia i zrozumienia mistycznej nauki Bożej o samym sobie i świecie. ,Tak zawsze bywa, kiedy umysł ogarnięty jest miłością Bożą, ciągnie samego siebie do samego rdzenia, porywa się do przodu silnym porywem, bo jest objęty Bogiem. Zapomina o wszystkim, zapomina także i o samym sobie i znajduje upodobanie tylko w Jednym, tylko w Tym, który jest okrążony mocami i czczony, któremu on spala w ofierze święte i niezbadane cnoty. Kiedy ucicha boski poryw i słabnie wielka chęć działa- nia, wtedy oddala się od boskości. Spotyka się on z człowieczeństwem i znowu staje się człowiekiem"36 - pisze Filon. Wówczas umysł cnotliwie przebywa w modlitwie i w modlitewnej ekstazie spotyka Boga w sercu. Człowiek zyskuje dostęp do drzewa życia - zdolności życia wiecznego z Bogiem, którego symbolem jest serce ${ }^{37}$. Doskonały umysł zdobywa wyższy typ cnoty - znajomość i zdolność kontemplacji Boga, którą można osiągnąć jedynie w sercu.

\section{Zakończenie}

Podsumowując można stwierdzić, że Filon z Aleksandrii pojmował serce jako zasadniczy organ w człowieku. Ta wyjątkowa ranga serca wynika nie tylko z jego powiązania z miłością, lecz również z podwójnego pojmowania serca - w sensie duchowym oraz materialnym. Serce oznacza całego człowieka, wraz z jego sumieniem. Filon z Aleksandrii podkreśla w swoich dziełach, że serca jest ściśle połączone z umysłem. Dzięki temu człowiek może doskonalić się w cnotach chrześcijańskich.

36 Е. Д. Матусова, Филон Александрийский, dz. суt., s. 47.

37 Филон Александрийский, О смешении языков, 161, [w:] Е. Д. Матусова, Филон Александрийский, dz. cyt., s. 333.

\section{Bibliografia}

Biblia to jest Księgi Starego i Nowego Testamentu. Nowy przekład z języków hebrajskiego i greckiego opracowany przez Komisję Przekładu Pisma, Warszawa 1990.

Filon Aleksandryjski, O stworzeniu świata, tł. L. Joachimowicz, Instytut Wydawniczy "Pax", Warszawa 1986.
Osmański M., Filon z Aleksandrii. Etyka upodabniania się do Boga, Wydawnictwo KUL, Lublin 2007.

Матусова Е. Д., Филон Александрийский, пер. и комм. А. В. Вдовиченко, М. Г. и В. Е. Витковские, О. Л. Левинской, вступ. ст. Е. Д. Матусовой, Москва 2000.

Rozmiar artykułu: 0,6 arkusza wydawniczego 


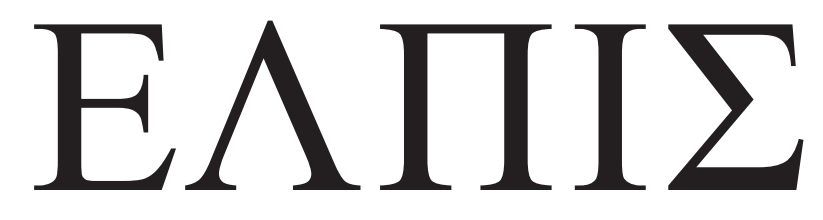

CZASOPISMO TEOLOGICZNE KATEDRY TEOLOGII PRAWOSŁAWNEJ UNIWERSYTETU W BIAŁYMSTOKU

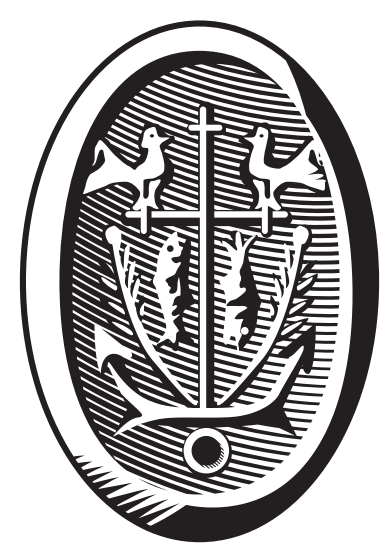

ADRES REDAKCJI

ul. Ludwika Zamenhofa 15, 15-435 Białystok, Polska tel. 85 745-77-80, e-mail: elpis@uwb.edu.pl www.elpis.uwb.edu.pl 